Vol. 4, No. 2, July 2020, pp. 119-145

Available at: https://ojs.unud.ac.id/index.php/UJLC/issue/view/3600

\title{
Indigenous Collaborative Governance: An Understanding of Decision-Making Process at Desa Adat in Bali, Indonesia
}

\author{
Md Putri Wiyantari Sutaryantha* \\ Department of Public Policy and Management, \\ Faculty of Social and Political Sciences, Universitas Gadjah Mada-Indonesia \\ Bevaola Kusumasari ${ }^{* *}$ \\ Department of Public Policy and Management, \\ Faculty of Social and Political Sciences, Universitas Gadjah Mada-Indonesia
}

Article Received: 6th March 2020; Accepted: 17 th July 2020; Published: 30 ${ }^{\text {st }}$ July 2020

\begin{abstract}
The decision-making process that took place at desa adat (indigenous village) involved many actors and stakeholders from various elements of the community, to achieve a common goal. This research highlights the linkages of indigenous collaborative governance among actors involved in the decision-making process at Balinese Desa Adat, Indonesia. This research has, thus, discovered how indigenous collaborative governance was linked to the decision-making process and linked to the implementation of local governance, especially in the implementation of Adat in Bali Province. This study emphasizes the extensive use of public administration literature about collaborative governance and the decision-making process. Additionally, in-depth interviews and live experience in desa adat were conducted, as it is aimed to explore and understand more about the case. The result provided aligned with the conceptual framework because all of the actual implementation of the decision-making process at Desa Adat Peliatan met the criteria or indicators of collaborative governance. It showed that there was an involvement of indigenous collaborative governance in the process of decision-making at the desa adat level. The practical implication, in this case, is that collaboration matters in the decision-making process involving various elements of society with diverse interests.
\end{abstract}

Keywords: Indigenous collaborative governance; Local decision-making; Desa adat.

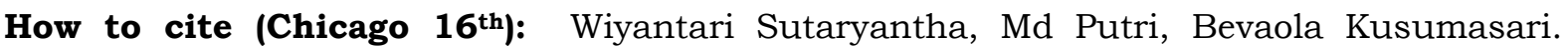
"Indigenous Collaborative Governance: An Understanding of Decision-Making Process at Desa Adat in Bali, Indonesia." Udayana Journal of Law and Culture 4, no. 2 (2020): 119145. https://doi.org/10.24843/UJLC.2020.v04.i02.p01.

doi: https://doi.org/10.24843/UJLC.2020.v04.i02.p01

\footnotetext{
*Email: putri.wiyantari.s@mail.ugm.ac.id

${ }^{* *}$ Email/Corresponding Author: bevaola@ugm.ac.id
} 


\section{Introduction}

\subsection{Background}

The existence of collaboration among actors and stakeholders at the local level, to carry out public purposes through a decision-making process established the background of this article. Although, some researchers have paid attention to the discussion of the collaborative governance ${ }^{1}$ and the decision-making process: ${ }^{2}$ however, there is still little that explains they both are correlated to each other. ${ }^{3}$ The correlation may be in a different context if we were looking from the viewpoint of the local governance, or in this case, in the context of the adat governance. Therein, thus, lies the significance of this research, because it provides the linkages of indigenous collaborative governance in an actual implementation of the decisionmaking process at desa adat in Bali Province, Indonesia.

The implementation of the collaborative governance, which integrates other non-state stakeholders as the main actors, has developed in the last few decades. As an advanced form of the governance system, the collaborative governance accommodates a wider scope of discussion relating to decision-making, policy formulation process, regulatory, and managerial process ${ }^{4}$. Collaboration at the local level was deemed necessary as a method of the decision-making process that was essential in creating trust. As a part of the public administration theory, collaborative governance was based on joint-venture and structural adjustment, which led to the term - publicprivate partnership. ${ }^{5}$ On the other hand, it also offered the opportunity for the implementation of the bottom-up approach, especially in dealing with

1 Jill M Purdy,. "A framework for assessing power in collaborative governance processes." Public administration review 72, no. 3 (2012): 409-417. See also: Erik W Johnston, Darrin Hicks, Ning Nan, and Jennifer C. Auer. "Managing the inclusion process in collaborative governance." Journal of Public Administration Research and Theory 21, no. 4 (2011): 699-721; Koski, Chris, Saba Siddiki, Abdul-Akeem Sadiq, and Julia Carboni. "Representation in collaborative governance: A case study of a food policy council." The American Review of Public Administration 48, no. 4 (2018): 359-373

2 B. Beresford, \& Sloper, T. Understanding the Dynamics of Decision-Making and Choice: a Scoping Study of Key Psychological Theories to Inform the Design and Analysis of the Panel Study. Social Policy Research Unit, University of York, 2008. See also: Robinson, Jennifer, Marta Sinclair, Jutta Tobias, and Ellen Choi. "More dynamic than you think: Hidden aspects of decision-making." Administrative Sciences 7, no. 3 (2017): 23. Coulter, Angela \& Collins, Alf. Making Shared Decision-Making a Reality. The King's Fund: London, 2011.

3 Chris Ansell, and Alison Gash. "Collaborative governance in theory and practice." Journal of public administration research and theory 18, no. 4 (2008): 543-571

4 Neil Gunningham, "The new collaborative environmental governance: The localization of regulation." Journal of Law and Society 36, no. 1 (2009): 145-166.

5 Bruce Perlman, "Introduction: Risks and Rewards in State and Local Collaboration" State and Local Government Review 43, no. 1 (2011): 46-48 
regional issues. ${ }^{6}$ The engagement between local people and the government somehow creates a certain level of democracy that is beneficial in determining policy innovation and mapping out of actors who were involved in the implementation. ${ }^{7}$

Collaboration in different scopes was also indicated by the existence of the desa adat system, which was strongly bounded with what is known as adat law and adat society. Desa adat system is the unity of adat law and society in the Bali Province, which is hereditary, has traditions and norms relating to Hinduism, and characterized by the existence of Kahyangan Tiga or the three main temples in a village ${ }^{8}$. Desa adat which has a wide area and is densely populated will usually be divided into several Banjar Adat, in which each of them is led by a Kelihan Banjar. The regulatory system in desa adat is inseparable from the provisions and regulations which apply in the village and are manifested in the Adat laws or called the Awig-Awig. The Adat law serves as a guideline for the life of the Adat community, it represents the traditions, customs, norms, and cultures that were already deeply rooted in the Adat community themselves. Those norms and culture eventually result in a force that binds the unity of the Adat community. Meanwhile, the Adat community is a unity of people bounded by the norms, customs, autonomy, and territorial ties, and they are able to govern the lives of their people in accordance with the prevailing customs. Customary law community or masyarakat hukum adat organizes their lives independently because they were born and formed by their own society, not by other forces.

As other general governance processes do, desa adat also applies the process of decision-making and policy formulation. The process itself embraces all relevant stakeholders from various interests and institutions to formulate the hukum adat or the customary law. According to Ter Haar in Susylawati, 9 hukum adat was established based on a decision that originated from the village legal officials, village judges, religious officials, and community leaders who were considered capable and trusted by the Adat community. A decision-making process is an important point of discussion, as this process will determine the moves of an organization through their chosen choice. For desa adat, the decision-making process is

6 J. Edwin Benton. "Local government collaboration: Considerations, issues, and prospects." State and Local Government Review 45, no. 4 (2013): 220-223

7 Margaret Weir, Leslie Lenkowsky, Romand Coles, and Patrick J. Deneen. "Collaborative Governance and Civic Empowerment A Discussion of Investing in Democracy: Engaging Citizens in Collaborative Governance." (2010): 595-607

8 Dewa Bagus Sanjaya. "Harmonisasi, Integrasi Desa Pakraman dengan Desa Dinas yang Multi Etnik dan Multiagama Menghadapi Pergeseran, Pelestarian, dan Konflik di Bali." Jurnal Ilmu Sosial dan Humaniora 2, no. 2 (2013). 265-274.

9 Eka Susylawati. "Eksistensi hukum adat dalam sistem hukum di Indonesia." AlIhkam: Jurnal Hukum dan Pranata Sosial 4, no. 1 (2013): 124-140 
a vital element because it is strongly related with the traditions and customs applied in the area, which must be adapted to the customary law (awigawig), and the technical guideline of the awig-awig (perarem). Given the diversity of parties involved in the decision-making process, it shows that genuine collaboration comes from the actors in the adat community in order to determine that the direction of the customary institutions was in accordance with the local traditions and norms. All of the decisions determined should be based on the agreement of all the collaborating actors in the decision-making process.

The real implementation of indigenous collaborative government in the decision-making process at desa adat level can be seen in Bali Province. Bali is one of the provinces in Indonesia that has strong cultural values and customs, which are widely known, and are still well-maintained. The culture and customs are not only strong in terms of religious matters, but also matters of governance and community regulatory systems. Therefore, the implementation of desa adat undoubtedly brought about a substantial influence in this region. The research was conducted in Desa Adat Peliatan, which is a desa adat located in Ubud District, Gianyar Regency, Bali Province.

\subsection{Research Problem}

There have been ample studies that discuss desa adat, such as the transfer of land status in desa adat, 10 Telajakan identification in desa adat, ${ }^{11}$ the role of desa adat's assemblies in the implementation of tourism investment in desa adat area, the legal standing and performance of the financial and banking institution in desa adat. Most of the problems that occurred in desa adat were resolved through decisions made by the stakeholders involved, yet there are still very few studies that explain how the actors collaborate in the decision-making process. This study attempts to fill the research gap by focusing more on the involvement of collaboration among actors by referring to indicators of collaborative governance, especially in the process of decision-making at the desa adat level. Therefore, based on the explanation above, the researchers feel that this is a very interesting topic to discuss, moreover, it aligns with a collaborative governance system, which indigenously originated from the people themselves. The problem that will be highlighted here in this study is, how

10 I. Nyoman Prabu Buana Rumiartha,. "Status of Village-owned Land Transfer Into the District Government Assets in Kintamani Bangli Bali." Jurnal IUS Kajian Hukum dan Keadilan 2, no. 3 (2014).601-614.

11 I.K.G.M Mahardika. A.A.G.D Sudarsana, \& A.A.G Sugianthara. Telajakan identification in Desa Pakraman Nyuh Kuning, Kecamatan Ubud Kabupaten Gianyar. EJournal of Landscape Architecture, 2 no. 1 (2016), 22-31 
indigenous collaborative governance is linked to the decision-making process at Desa Adat Peliatan? This study is, furthermore, aimed to discover the linkages of indigenous collaborative governance in the decision-making process that related to the task of desa adat as stated in Article 22 of Regional Regulation of Bali Province No. 4 of 2019 concerning Customary Villages in Bali. Hence, this article is divided into several parts, which are the introduction, literature review, research methodology, case study, analysis and discussion, and conclusion.

\subsection{Method Outline}

This article on indigenous collaborative governance in the decisionmaking process was carried out by using the qualitative method with a case study approach. Researchers employ qualitative methodology in order to acquire more detailed and in-depth analysis results, which work well for processes involving norms and values, life experiences, culture and customs of a certain tradition, and sensitive issues by conducting in-depth interviews and focusing on the group discussions directly at the source of study ${ }^{12}$. In addition, the case study approach is one of the approaches in qualitative research that is intensively conducted, as an empirical investigation of a real-life phenomenon in a specific context, in an explored and elaborated way, which was carried out holistically and comprehensively ${ }^{13}$. This research uses a case study approach by providing specific case example of the implementation of indigenous collaborative governance in the decisionmaking process at the local level in Desa Adat Peliatan, Ubud Sub-district, Gianyar Regency, Bali Province. The qualitative approach was utilized in order to gather more specific information relating to the collaboration process in Sabha Desa or the process of decision-making at the desa adat level.

There are two types of sources used in this study, which are primary and secondary data. The primary data is data or information directly acquired from the people or situation under study ${ }^{14}$, in which data was gathered through observations conducted at desa adat, also via interviews with the people or stakeholders involved. In this research, several interviews were carried out with the stakeholders such as bendesa or a leader who responsible about adat and Kelihan banjar or the head of the village organization group in Desa Adat Peliatan, namely: 1) I Ketut Sandi (Bendesa

12 J. Atkinson. Qualitative Methods. In Journey into Social Activism: Qualitative Approaches pp. 65-98. New York: Fordham University, 2017

${ }^{13}$ Robert K Yin. Case Study Research: Design and Methods. Thousand Oaks, CA: Sage, 2009

14 Phyllis Tharenou \& Donohue, Ross. \& Cooper, Brian. Management Research Methods. Cambridge: Port Melbourne, Victoria: Cambridge University Press, 2007 
Desa Adat Peliatan), 2) I Made Sandiyasa Astawa (Kelihan Banjar Yangloni, Desa Peliatan), 3) I Nyoman Suparta (member of Sabha Desa \& Kelihan Pura Puseh Kahyangan Tiga Desa Adat Peliatan), 4) Made Suardana (former Bendesa Desa Adat Peliatan and Paritula in Sabha Desa), 5) I Wayan Sumada (Kelihan Banjar Teges Kanginan, Desa Peliatan), 6) Luh Pande Nusarini (community leader of Desa Peliatan and member of Sabha Desa), and 7) I Made Dwi Sutaryantha (community leader of Desa Peliatan). Numerous observations were also conducted to see what occurred on the field, in order to facilitate the extraction of information relating to the decision-making process in the indigenous collaborative governance at Desa Adat Peliatan. The researcher's participation in discussions and meetings of desa adat had also been beneficial in order to obtain more accurate information about the case under examination. Furthermore, the secondary data which consist of the data collected by other people for their primary purposes ${ }^{15}$ was obtained by conducting literature reviews of various documents, such as journals, books, newspapers, law and regulations, and awig-awig and pararem. This secondary data, as supporting documents, contributed to providing more understanding and explanation in relation to the topic of this research.

\subsection{Literature Review}

\subsubsection{Collaborative Governance}

In building a further concept of indigenous collaborative governance, basic frameworks of collaborative governance were needed to define the theoretical background used in this article. Governance in terms of collaborative governance means structures, processes, rules, and traditions related to the process of decision-making, and the actualization of accountability ${ }^{16}$. Meanwhile, collaboration means a process of governance that is used to describe an engagement of various societal actors to act in a joint-venture activity ${ }^{17}$. By considering the definition above, collaborative governance is defined as a process and structures of public policy and decision-making which engage people across the boundaries from all levels of the community, in order to carry out a public purpose. A similar

15 Erik W Johnston, Darrin Hicks, Ning Nan, and Jennifer C. Auer, op.cit.

16 S Zadek. \& Radovich, S. Governing Collaborative Governance: Enhancing Development Outcomes by Improving Partnership Governance and Accountability. John F. Kennedy School of Government: Harvard University, 2006.

17 Ricardo S Morse and John B. Stephens. "Teaching collaborative governance: Phases, competencies, and case-based learning." Journal of Public Affairs Education 18, no. 3 (2012): 565-583 
definition was also offered by Warm ${ }^{18}$, regarding collaboration in local government, wherein collaboration involves working across institutional boundaries to engage with external individuals and entities in a highly connected way of decision-making and service delivery. It is also cooperation among stakeholders involving government and non-government sectors in addressing public issues.

Further mentioned in another literature, collaborative governance is a governing arrangement where public agencies directly engage non-state stakeholders in a decision-making process, which aims to implement the public policy for the people. By involving non-state stakeholders such as NGO, media, local authorities or private sectors in the decision-making process, they have a direct responsibility to the policy outcome and are directly engaged in the process themselves. Collaborative governance is also defined as a relationship between government as principal or the regulator and private agents, by engaging people constructively across the boundaries, to carry out public purposes. ${ }^{19}$ Governance needs to establish collaboration in order to gather multiple perspectives and provide opportunities for local actors to contribute in giving new understanding ${ }^{20}$.

In relation to all of the explanation concerning collaborative governance above, it can thus be redefined as a new form of government which was executed by involving stakeholders outside the boundaries in the decision-making process, to take a shared-responsibility in implementing public policy based on the norms and values applied in the circumstances. The existence of a collaborative government was prompted by a sense of relationship reciprocity and mutualism among the stakeholders involved to achieve goals that apply to their common needs and interests.

\subsubsection{Indicators of collaborative governance}

In achieving collaborative governance, there should be some key elements that are required to be applied in the system. There are several key elements as well as indicators for the managed network that works in collaborative governance, which are: 1) networked structure, 2) commitment to a common purpose or mission, 3) trust, 4) governance, 5) network management, 6) access to authority, 7) leadership, 8) distributive accountability and responsibility, 9) information sharing, and 10) access to

18 David Warm. "Local government collaboration for a new decade: Risk, trust, and effectiveness." State and Local Government Review 43, no. 1 (2011): 60-65

19 Kirk Emerson, Tina Nabatchi, and Stephen Balogh. "An integrative framework for collaborative governance." Journal of public administration research and theory 22, no. 1 (2012): 1-29.

20 Blake D Ratner, Benoy Barman, Philippa Cohen, K. Mam, K. Nagoli, and Edward H. Allison. "Strengthening governance across scales in aquatic agricultural systems", 2012 
resources. ${ }^{21}$ These elements make it possible for collaborative governance to be used as a broader analysis in public policy decision making involving individuals across public institutions, levels of administration, private sphere to achieve a public purpose otherwise unable to achieve. Further explanation of each key element will be given below:

The first key element is networked structure and technology, this means that in implementing collaborative governance, the authority formed by all of the stakeholders involved must be in a balanced position, implying that no particular party should take part as a dominating element in the structure. Domination in a collaborative system may trigger gap authority, which in the future may cause more substantial disputes. The second one is commitment to a common purpose or mission, it shows approval from the members to achieve positive results in this joint-venture activity. The Third is trust, which means that all of the members in the system or organization trust each other to work together in achieving common goals ${ }^{22}$, and it is needed as a means to establish a more professional relationship among the people in the structure.

The fourth key element is Governance, which is the arrangement of stakeholders that are involved in the collaborative system, it contains the rules and regulations to govern the members of the system. It is also related to the determination of whether someone belongs as a member of the organization or not. Subsequently, the fifth element is network management, meaning people involved in the collaboration can create strategic coordination among actors and develop the ability to solve problems, to tackle issues that are likely to happen in the organization through the networks ${ }^{23}$. The sixth element is access to authority means that there should be clear procedures and requirements in running the collaborative governance system, in regards to the responsibilities and authorities performed by the authority holders, which have been accepted by all of the members. The seventh key element is Leadership, which is defined as a social process in dynamic collaboration wherein the stakeholders and members of the organization develop interaction in a new form of social meaning.

The eight element is distributive accountability and responsibility are important in every organization, especially in the implementation of collaborative governance. In collaborative governance, the distribution of

${ }^{21}$ S. Goldsmith and Donald F. K. Unlocking the power of networks: keys to highperformance government. Brookings Institution Press: Washington, D.C, 2009

22 Michael Pirson and Deepak Malhotra. "Foundations of organizational trust: What matters to different stakeholders?." Organization Science 22, no. 4 (2011): 1087-1104

23 Anthony M Bertelli and Craig R. Smith. "Relational contracting and network management." Journal of Public Administration Research and Theory 20, no. suppl_1 (2010): 121-140. 
accountability and responsibility shows the quality level of good governance, because it means they have carried out good management and arrangement in their collaboration to achieve the desired goals. The ninth element is Information sharing means there is a new way of finding solutions, by bringing the data in one place to obtain clear data and information and resolve different issues through different perspectives ${ }^{24}$. Collaborative governance involves people from numerous differing backgrounds and parties, and that is why a well-defined information distribution is required, to avoid misunderstanding. The last element is access to resources means that clarity and availability of resources (e.g. financial, technical, human, and other resources) in executing collaborative governance need to be regularly maintained for the stakeholders involved in the collaboration. All of the programs that an organization intends to conduct would definitely require adequate resources to realize.

\subsubsection{Indigenous collaborative governance}

According to the definition in the Cambridge Dictionary, indigenous is described as something that operates or is happening in the local area, not in other places ${ }^{25}$. Additionally, indigenous is defined as something that is produced, growing, living, and occurring naturally in a particular area. Indigenous in this study is used as a term to explain a collaboration, which originated from a place where such kind of collaboration was conducted, and cannot be found anywhere else. Such indigenous collaborative governance was applied because the local community desires its existence, by adjusting to the needs and customs applied in the area. This term also represents the bottom-up approach of collaboration, wherein this kind of activity originated from the people and adat community itself, in order to achieve the desired goals and objectives they have previously determined. In this study, the term indigenous can be defined as adat or norms and customs that apply in a certain area of the community. In the implementation of adat governance and regulation in Bali, the stakeholders are involved as actors without boundaries, in order to embrace all of the existing interests, and conduct cultures and traditions that were applied in the region. Cooperation is of utmost importance in such indigenous collaborative governance because all matters they have agreed on will be run and conducted by the people themselves.

${ }^{24}$ B. Jackson, How do we know what information sharing is really worth? Exploring methodologies to measure the value of information sharing and fusion efforts. In How Do We Know What Information Sharing Is Really Worth? Exploring Methodologies to Measure the Value of Information Sharing and Fusion Efforts (pp. 1-32). RAND Corporation, 2014.

25 https://dictionary.cambridge.org/dictionary/english/indigenous 


\subsubsection{Decision-Making Process}

A decision is a result of problem-solving and a choice among choices about what is the best thing to do. The decision-making process is a process of choosing an alternative among many alternatives or choices, in order to achieve goals and objectives that are predetermined. It is also a process of determining possibilities in uncertain situations. Other scholars added that decision-making is a process of problem-solving for a complex and unstructured problem, by considering several alternatives to achieve desired goals $^{26}$. On the other hand, the decision-making process commonly involves a decision problem, which is under the consideration of decision-makers, to find an opportunity through the decision-making process in solving the problems. The Decision-making process is also characterized by the existence of pronounced differences, which creates more dynamics and alternative choices in the process ${ }^{27}$.

A similar definition was also offered by Li, wherein decision-making is about making the best choice among choices and several options, based on the currently occurring situation. ${ }^{28}$ It is an important component in deciding something related to a more complex problem, for example, negotiation, public policy, control and command, and others. The Decision-making process is substantial in public administration because the quality of the decisions will affect the resulting performances of certain institutions and organizations. ${ }^{29}$ It is also a process of deliberation involving the thought of an individual towards a social phenomenon. ${ }^{30}$ The process of decisionmaking occurs due to existing problems that need to be solved, and the decision-makers should be able to find opportunities and alternatives to handle those problems. ${ }^{31}$

Based on all of the definitions pertaining to the decision-making process, it can be concluded that the decision-making process is a process of choosing the best decision from several choices or alternatives, in order to

26 David H Jonassen. "Designing for decision making." Educational technology research and development 60, no. 2 (2012): 341-359

27 Alessandro Scopelliti. "The Political Decision-Making Process in the Council of the European Union under the New Definition of a Qualified Majority." Il Politico (2008): 180210

$28 \mathrm{Bin} \mathrm{Li.} \mathrm{"The} \mathrm{classical} \mathrm{model} \mathrm{of} \mathrm{decision} \mathrm{making} \mathrm{has} \mathrm{been} \mathrm{accepted} \mathrm{as} \mathrm{not} \mathrm{providing}$ an accurate account of how people typically make decisions." International Journal of Business and management 3, no. 6 (2008): 151-154.

29 Fred C. Lunenburg, "THE DECISION MAKING PROCESS." In National Forum of Educational Administration \& Supervision Journal, vol. 27, no. 4. 2010.

${ }^{30}$ Hussien Ahmad Al- Tarawneh, "The main factors beyond decision making." Journal of Management Research 4, no. 1 (2012): 1-23.

31 Oriana-Helena Negulescu,. "Using a decision-making process model in strategic management." Review of General Management 19, no. 1 (2014): 111-123. 
achieve predetermined goals and objectives. It is a process of deciding something in order to determine the best solution for a problem or case, which is highly crucial particularly in the policymaking process.

\subsubsection{Stages of the Decision-Making Process}

Herbart A. Simon ${ }^{32}$ mentioned there are at least three stages of the decision-making process, which are: 1) investigation, 2) designing, and 3) choosing the best choice or alternative. An investigation is a stage in which stakeholders involved in the decision-making process would identify the problem and case, requiring a decision by collecting data and determining what is going on with the problem. Designing means the decision-makers will analyze and arrange steps and alternatives which they may take to make a decision based on the problem previously formulated. Lastly, choosing the best choice or alternative is about the act of decision-makers in selecting the best choice or alternative based on what they had previously set for their next action.

\subsubsection{Institutions and Social Institutions}

According to Uphoff in Ohorella, S., Suharjito, D., \& Ichwandi, an institution is a set or an order of norms and customs which has been implemented based on existing characters and behaviors, to achieve common goals. ${ }^{33}$ Institutions can also be defined as a structure of social interactions that apply existing social rules to govern the people within the structure. ${ }^{34}$ Whereas social institution here is defined as a collective normative social practice which involves new concepts, practices, and elements to solve existing problems. ${ }^{35}$ The functions of social institutions are: 1) to provide code of conduct, 2) to maintain unity within the society, 3) to serve as social control for the society, and 4) to fulfill the needs of the society. ${ }^{36}$ In Indonesia, the institution of Adat is related to a social

32 Ahmad. "Kebijakan dan Pengambilan Keputusan Dalam Lembaga Pendidikan Islam." Al-Ta lim Journal 20, no. 2 (2013): 373-379

${ }^{33}$ Syarif Ohorella. Didik Suharjito, and Iin Ichwandi. "Efektivitas kelembagaan lokal dalam pengelolaan sumber daya hutan pada masyarakat Rumahkay di Seram Bagian Barat, Maluku." Jurnal Manajemen Hutan Tropika 17, no. 2 (2011): 49-55..

34 Geoffrey M Hodgson."What are institutions?." Journal of economic issues 40, no. 1 (2006): 1-25

35 Raimo Tuomela. "Collective acceptance, social institutions, and social reality." American Journal of Economics and Sociology 62, no. 1 (2003): 123-165

36 Tyas Widyastini and Arya Hadi Dharmawan. "The Effectiveness of Awig-awig in Livelihood Arrangements of Fishing Community in Kedonganan Beach." Sodality: Jurnal Sosiologi Pedesaan 1, no. 1 (2015) 
organization that has the objective of maintaining norms, customs, traditions, and culture of the Adat itself. ${ }^{37}$

\subsubsection{The Role of Adat in Public Policy Agenda}

Adat exists to represent norms, customs, and traditions that have been prevalent for a long time in the social community ties. Since adat is an original product of the local community, all of the adat community's affairs should be based on the prevailing customs. All of the public policies which will be applied in the adat community shall be based on their norms and customs, and not contrary to the adat's law or awig-awig. The adjustment of public policy is a means of preserving local wisdom, in order to uphold locality values and maintain Indonesian multiculturalism. Adat as a form of local wisdom has a certain role in the region's public policy agenda. Adat can be positioned as a controller of the politic climate to the central government from the local level, to produce a healthier political relationship between the central and the local governments ${ }^{38}$. The adat contributions in determining public policy will most likely provide more open political space for the local communities. Such kinds of contribution and cooperation are needed to accommodate all the aspirations of the people, which will further have an impact on enhancing the level of democracy throughout the country.

In the following is a diagram describing the decision-making process that involves relevant stakeholders in Desa Adat Peliatan:

37 Van Ast, Jacko A., Anindya Widaryati, and Mansee Bal. "The 'Adat'institution and the Management of Grand Forest 'Herman Yohannes' in Indonesian Timor: The Role of Design Principles for Sustainable Management of Common Pool Resources." Conservation and Society 12, no. 3 (2014): 294-305

38 J.S. Davidson, Henley, D., \& Moniaga, S. Adat Dalam Politik Indonesia. Jakarta: Yayasan Pustaka Obor Indonesia, 2010 


\section{Figure 1. Decision-Making Process in Desa Adat Peliatan}

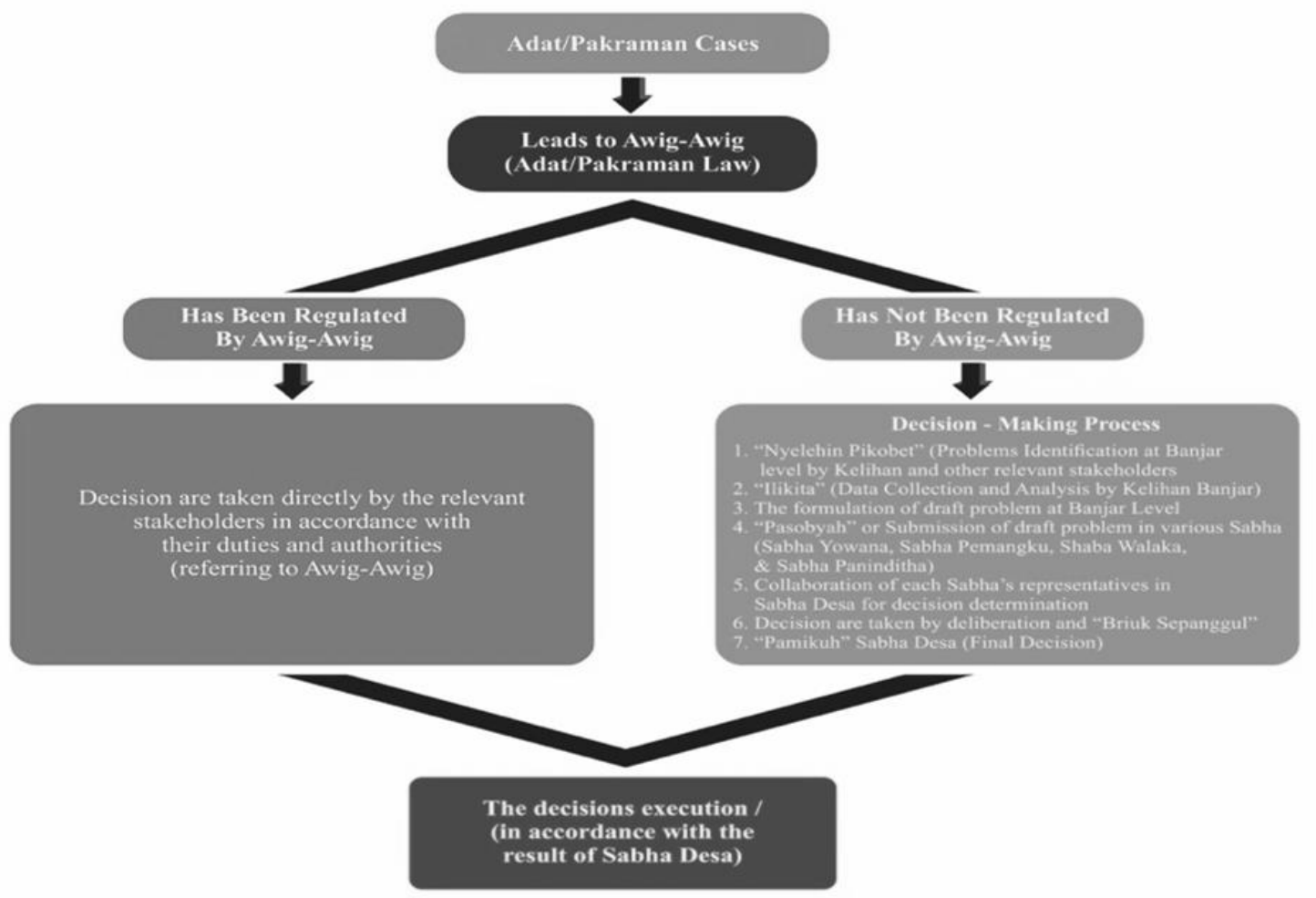

\section{Result and Discussion}

Generally, results of this study show that there was indeed a collaboration conducted through adat in the decision-making process that related to Balinese adat and Hinduism in its territory, particularly at Desa Adat Peliatan which is the research object in this study. Desa adat in Bali is stated clearly in the Regional Regulation of Bali Province No. 4 of 2019 concerning Customary Villages in Bali. This regulation does not refer to Law No. 6 of 2014 concerning Villages, but rather refers to Article 236 paragraph (4) of Law No. 23 of 2014 concerning Regional Government, which states that regional regulation can contain material locally in accordance with statutory provisions. According to this regulation, desa adat has territories, original rights, traditional rights, original arrangements, and original autonomy to regulate and manage their own households. It is also through this regulation that for the first time the desa adat is officially and explicitly recognized as a legal subject with a clear and firm legal position. Therefore, the basic principle of this regional regulation is not deviate from local wisdom. The fundamentals must be perpendicular to local wisdom. What is interesting from the decision-making process carried out in desa adat is the prevailing collaboration among stakeholders, in determining the best measures to take in addressing a problematic issue. As implemented by Desa Adat Peliatan, when they were confronted with a problem they have never encountered before, or something they are yet to make provision for in awig-awig, they would have to determine their stance by undertaking a 
decision-making process. It is in this very process that adat (custom) based collaborations are found, wherein numerous community figures from various elements of interest involved are accommodated in an assembly that is called Sabha Desa.

Every decision made in desa adat was a result of mutual agreement achieved in the Sabha Desa based on the principles of deliberation and consensus. This means that every decision made in desa adat constantly involves actors deemed capable of contributing to the decision-making process. The actors' involvement in the decision-making process was found to be directly evident at Desa Adat Peliatan. The continuity of theoretical analysis in the literature review, and the implementation of the case study in Desa Adat Peliatan can be observed in the following elaboration of collaborative governance indicators:

\subsection{Networked Structure}

The indigenous collaborative governance in Desa Adat Peliatan vividly illustrates a form of network structure, in which all parties involved in the decision-making process are positioned at an equal level without any hierarchy suggesting a form of dominance. All of the individuals present in the Desa Adat Peliatan system are combinations of varying elements with differing interests, albeit grounded by common goals. It is these common goals that have allowed the collaboration to continue to this day in

The implementation of multi-party collaboration in the decisionmaking process in desa adat can be discerned from the structure of Sabha Desa Adat Peliatan, which is a representation of the respective element found in Desa Adat Peliatan. According to Awig-Awig Desa Adat Peliatan, Sabha Desa consists of the Village Head of Peliatan as the "Pengayom" (protector) or person in charge, there are also several "Paritula" or advisors who come from circles of influential community figures, such as Puri or royal figures and Griya or spiritual figures. And then, Bendesa Desa Adat was positioned as the leader of Sabha Desa or which is called "Manggala." Sabha Desa also has a secretary or "Penyarikan" and a treasurer or "Patengen" with the task of assisting Bendesa Adat. Sabha Desa Adat Peliatan comprises of various members coming from various relevant sectors in the desa adat structure. The members are Kelihan Pura Kahyangan Tiga Desa Adat Peliatan, the Kelihan Banjar from each of the Banjar in Desa Adat, Kelihan Pakaseh of Pura Gunung Sari that relates to farming and agriculture, and the Kelihan Sekaa Teruna of the respective Banjar in Desa Adat Peliatan or individuals associated with the youth organization. In addition to the aforementioned people, Sabha Desa members also include several community figures who are considered to have the capacity to provide significant contributions in the decision-making process, such as 
the Family Welfare Movement (PKK) or the women organization of Desa Adat, "Pecalang" or security organization and other community figures in Desa Adat Peliatan.

Bendesa, who in this case is the head of desa adat, was tasked to oversee the implementation of Sabha Desa. In the decision-making collaboration process, every actor involved has an equal voice regardless of the official position they have. All of the components are involved fairly and equally without any individual dominance. The decisions in Sabha Desa Adat Peliatan are made through "briuk sepanggul" without the use of a voting system. "Briuk sepanggul" is a term used to describe a mass behavior or actions that follow the voice of the masses ${ }^{39}$. "Briuk sepanggul" is also a means of making a decision based on a shared mutual voice. Aside from "briuk sepanggul," there are also some guidelines employed in making decisions at desa adat, namely "paras paros sarpanaya salulung sabayantaka" which means deliberation and consensus in both happiness and sorrow.

The system of "Briuk sepanggul (respect each other)" and "paras paros sarpanaya salulung sabayantaka (many hands make light work)" in the decision-making process in desa adat facilitate decision-makers to determine their resolve by considering the shared voice of the people. Briuk sepanggul allows all members agree simultaneously at the time of the decision making process. Briuk sepanggul ensures that, essentially, the decision is a mutual agreement. Since there is usually intense discussion in the forum in advance of the compilation of opinions. When all thoughts and viewpoints have actually been shared, generally leaders who pose questions like "what does the matter mean whether this is acceptable or not?". There will normally be those who say that they agree or disagree and then all debate participants obey as it was the consensus process before they took one another's views. At the same time, paras paros sarpanaya salulung sabayantaka means people can do things more quickly and easily when they have sense of togetherness. The implementation of these two systems allow stakeholder to make a decision based on a collective approval because it represents the respects and honesty of each stakeholder. Therefore, the voting system has never been applied in decision-making at Desa Adat Peliatan in order to avoid the formation of coalition groups, that in the future is feared to devastate the mutual system instead. This also indicates that there is no particular element or voice that dominates or stands in power in the indigenous collaborative governance process, mainly in the decision-making process at Desa Adat Peliatan. The theory of networked structure does work in the system of Desa Adat Peliatan.

39 I.W. Damayana. Menyama Braya: Studi Perubahan Masyarakat Bali. Salatiga: Universitas Kristen Satya Wacana, 2011 


\subsection{Commitment to a Common Purpose or Mission}

Anyone who has an official position or has contributed in the administration of desa adat, is a committed individual since they conduct these administrative activities on the basis of "ngayah" or a form of sincere and genuine service without expecting any reward in return. Given such a statement, it can thus be considered that the involvement of all Sabha Desa members who have provided various contributions and taken part in the decision-making process in desa adat is a form of commitment to a common purpose or mission. The fact that the members are not forced against their will to participate is also another form of commitment shown by the decision-makers of desa adat.

Additionally, this commitment is also reinforced by having a vision and mission of Desa Adat Peliatan in place, and they are stipulated in AwigAwig Desa Adat Peliatan, which are strengthen and maintaining religious teachings, prioritize implementation of religious teachings properly, and maintaining spiritual and physical welfare of the village and its community, of this life and the next. Having a common purpose that people want to pursue in the implementation of desa adat is also regarded as a commitment to a common purpose or mission because their objective serves as the rationale as to why they collaborate and are committed in a process of decision-making in desa adat. One example of how the commitment to a common Purpose or Mission is the formulation of awig -awig regarding the joint management of the Tanah Setra (grave) in Desa Adat Peliatan. This awig-awig then becomes a strong and binding legal basis as a guideline for indigenous in desa adat. In the awig-awig formulated, it was agreed that if there was a violation of the agreement, the sentence given would not only be physical punishment but also a fine of $35 \mathrm{~kg}$ of rice ${ }^{40}$.

\subsection{Trust}

As previously mentioned on networked structure, the decision-making process in desa adat is fundamentally based on deliberation and consensus attained through shared discussions held by the relevant stakeholders. The mutual agreements achieved through these discussions are results that indicate the presence of trust fostered among stakeholders to carry out their mission of accomplishing a common goal. Additionally, it is also known that the implementation of Desa Adat Peliatan is supported by numerous factors

40 A.A. Gd. Bgs.Trisna Ari Dalem, A.A. Istri Ari Atu Dewi,; I Gusti Ngurah Dharma Laksana. Eksistensi Pengelolaan Bersama Tanah Kuburan (Setra) Di Desa Pakraman Peliatan Ubud-Gianyar. Kertha Desa, 1 no 1 (2018), 1-16. 
both external and internal, such as collaborations with desa dinas and human resources involved in the desa adat structure itself.

Furthermore, the cooperation Desa Adat Peliatan has with Desa Dinas Peliatan are apparent in desa adat's channel for activity funding assistance that has to go through the Village Budget (Anggaran Pendapatan dan Belanja Desa - APBDes). Whatever activity or recommendation desa adat intends to suggest, it should initially be conveyed via the budget prior to eventually being transferred to desa adat and be independently managed according to their Articles of Association or Bylaws (Anggaran Dasar/Anggaran Rumah Tangga - AD/ART). The implementation of Desa Adat Peliatan activities has been able to run properly to this day is undoubtedly due to the influence that the level of trust among all of the support systems of Desa Adat Peliatan has. Elaborations on the link between Desa Adat Peliatan and Desa Dinas Peliatan as well as the deliberation/consensus agreement show that there is a mutual sense of trust among the stakeholders involved to support the success of activities implemented in Desa Adat Peliatan.

\subsection{Governance}

The Desa Adat Peliatan system has a clear structure in the collaborative process of decision-making in Sabha Desa, as provisioned in Awig-Awig Desa Pakraman Peliatan. The membership of those involved in the decision-making process is described in detail as to who are the members of Sabha Desa and who are not. Additionally, several procedures have also been determined in the implementation of Desa Adat Peliatan, which are awig-awig, perarem, and sima dresta. Every awig-awig and decisions made by desa adat are documented based on the Awig-Awig Composition Guideline and Village Decree as stipulated by the Law and Human Rights Bureau of the Bali Province Regional Secretariat ${ }^{41}$. Awig-awig has been regulating all matters relating to the implementation of desa adat, which also relates to matters considered to be either conforming to the standard norm or otherwise. Perarem is a technical guideline in the implementation of awig-awig, which also regulates in more specific details matters relating to the implementation of awig-awig at Desa Adat Peliatan. Whereas sima means the stake that marks the boundary of an area, and dresta means manners of social life in a desa adat. Sima and dresta are also basic rules that have indeed been applied since a long time ago and they remain to be implemented until today, as they are regarded to be of utmost importance and feasible to carry out.

${ }^{41}$ W.P. Windia, Hukum Adat Bali: Aneka Kasus dan Penyelesaiannya. Department of Culture in Gianyar Regency \& Udayana University Press, 2015 


\subsection{Network Management}

The partnership fostered between desa dinas and desa adat in Peliatan is a form of support to the existing collaboration among the stakeholders involved to resolve the issues mutually. Goldsmith and Donald $^{42}$, mention that network management concerns the strategic means developed by collaborative actors in order to launch every collaboration activity to achieve a common goal. Reflecting on the Peliatan case, network management was observed to take place across several organizational units that consist of people from numerous varying interests; yet, they also collaborate in the decision-making process. Both of them have their own problems to address in Sabha Desa, and that is why they are participating in the joint-venture activity as a strategic means to mutually resolve common problems. This also indicates that the indigenous collaborative governance process in Desa Peliatan is the accumulative result of the support given by stakeholders, who come from various sectors, being involved in the process.

Upon observation of Desa Adat Peliatan's implementation, the linkages and collaboration of the various societal elements were clearly apparent in the "Pasobayan" process, which is a process of disseminating information regarding the draft of issues to be discussed in Sabha Desa. Such information was disseminated to various elements in desa adat who were involved in the process of decision-making in Sabha Desa, such as the youth organization, the advisor from the Brahmana, and Ksatria classes, and other groups who are deemed influential in the process. Having various relevant elements involved in the decision-making process at Sabha Desa also indicates that management of network exists in this process. All elements assemble and engage in mutual synergy to resolve common problems they share and to fully support collaboration and partnership in the decision-making process.

The example of network management can be seen when decisionmaking regarding assistance due to the Covid-19 pandemic that entered Desa Adat Peliatan. The collaboration of the village and traditional offices in Peliatan went very well, the decision making included all the elements in desa adat to be involved. They divided roles to face the current pandemic together. For instance, desa adat, which will make regulations that are usually unwritten, is related to the prohibition of the community to go out, to limit what time the shops should open, and their service will play a role in receiving logistical and data collection assistance.

${ }^{42}$ S., Goldsmith and F. K. Donald. Unlocking the power of networks: keys to highperformance government. Brookings Institution Press: Washington, D.C, 2009. 


\subsection{Access to Authority}

There are several general matters that have become a standard in resolving problems at Desa Adat Peliatan. This can also be observed from the role of Kelihan Banjar, as the leader of the sub-unit called banjar which is under desa adat, who has direct access to the community. If a problem was to take place in desa adat, the first response would be carried out at the Banjar level with Kelihan Banjar, as the main actor who will determine the process for resolving the said problem.

In Desa Adat Peliatan, the means of resolving problems that occur at desa adat have been provisioned in awig-awig or perarem; hence, decisions will be made immediately by the relevant stakeholder, of which in this case is anyone responsible to assist in resolving that problem. This means that if a problem occurred and its resolution has been regulated in awig-awig, in line with the prevailing stipulations, then that problem could immediately be resolved by the relevant actors, without having to undergo the decisionmaking process held in Sabha Desa. The relevant actor here is primarily the Kelihan Banjar as the initial actor who directly interacts with the community in confronting the currently occurring problem.

This is also in accordance with the access to authority concept because the actors involved in the process have the authority to resolve their problems, according to the general operating procedures that have been widely determined and agreed upon. The implementation of the access of authority concept in Desa Adat Peliatan is shown by the role of Kelihan Banjar who has access to determine the subsequent measures they should take in resolving an issue.

\subsection{Leadership}

Based on the result of interviews conducted with the former Bendesa Desa Adat Peliatan, the members of Sabha Desa involved in the process are representatives of the leading figures, who were entrusted by the community to represent their voice and concerns in the decision-making process. It can thus be stated that the selection of leaders in the various societal elements found in the village was determined through a bottom-up approach, in which the community themselves decide who they want to represent them, and then they afford their trust to this particular person to serve as a leader in Desa Adat Peliatan. Leadership in Sabha Desa Peliatan is not only shown through the role of Bendesa as chief of assembly but also throughout the entirety of the stakeholders involved, particularly those who possess the experience and are capable of providing solutions to the issues they confront. It can be said that all the representative elements involved in the indigenous collaborative governance in the process of Sabha Desa Peliatan are leaders in their respective community group, they are individuals with 
Indigenous Collaborative Governance: An Understanding of Decision-Making Process at Desa Adat in Bali, Indonesia

Md Putri Wiyantari Sutaryantha and Bevaola Kusumasari

the capacity and potential to influence others and contribute to the decision-making process at Desa Adat Peliatan.

\subsection{Distributive Accountability and Responsibility}

The stakeholders' involvement in the decision-making process within the concept of indigenous collaborative governance shows the actual implementation of distributive accountability and responsibility. In the implementation of Desa Adat Peliatan, all members of Sabha Desa involved have an equal load of resolving problems, and no particular party should feel that they have gained more benefit or have been more disadvantaged than the others. They have an equal responsibility to resolve their issues and are committed to achieving a common goal in desa adat. Every Sabha Desa member involved in the decision-making process engaged in a mutual synergy when examining an issue, by referring to the prevailing customary laws or Awig-Awig and pasuara or technical consensus agreed upon on the field. It can be seen from the implementation of the Rurung Peliatan Festival, which makes decisions to determine themes based on local wisdom. In the process of decision making, every Sabbha Desa member is involved and agreed that the theme of the festival is about Farmer Behavior. This topic has put forward the potential in the Pelitan Indigenous Village. The issues desa adat confronts varies, and not all of them were written or regulated in awig-awig. as the problems faced by Desa Adat Peliatan. Hence, a decisionmaking process in desa adat was required to accommodate all existing interests and affairs of desa adat that are considered necessary, but have yet to be codified or regulated in awig-awig. There are several procedures available for resolving problems confronted in desa adat, the first step is that the problem will be initially resolved by Kelihan Banjar; if it is not resolved, then it will be brought to Paruman Banjar (Banjar assembly), if it is not settled in the Banjar meeting, then it will be brought to the attention of Bendesa Adat. It does not stop there if the problem remains unresolved at the Bendesa Desa Adat, then the decision-making process relating to that problem will eventually be discussed in Sabha Desa. Sabha Desa is a meeting forum in desa adat that functions as a venue to make decisions as well as to implement the teachings of Tri Hita Karana and the actors of desa adat (Awig-Awig Desa Adat Peliatan). Sabha Desa or Sangkepan Desa is a manifestation of democracy at the desa adat level, particularly in managing their own household through the autonomy system.

Every stage carried out in the process of problem-solving at Desa Adat Peliatan has differing processes and actors; yet, they have the same objective of resolving an existing problem. The process shows that there is equal distribution of accountability and responsibility, wherein every actor 
involved must be capable of bearing responsibility and resolving problems mutually in a forum called Sabha Desa.

\subsection{Information Sharing}

Collaboration in the decision-making process at Desa Adat Peliatan involves various elements in the community, as a form of equality and openness of information access to the whole community. Having numerous elements of the community gathered in collaboration, to make decisions will surely disseminate information in a more rapid, effective, and efficient manner since clear structure and mechanism are already present in that process.

The process of information sharing can further be witnessed in the actual implementation of Desa Adat Peliatan. As previously mentioned, Desa Adat Peliatan comprises of several Banjar Adat in Desa Peliatan and some Banjar Adat in Desa Ubud. Having linkages of membership that involve other villages in the Desa Adat Peliatan administration requires Desa Adat Peliatan to communicate with other related parties, particularly in the decision-making process. This very open access to information is one of the key elements of collaboration at Desa Adat Peliatan, particularly in the decision-making process, because this village also involves territorial areas of other regions, which require them to keep maintaining good communications and open access to information between one another.

Desa Adat Peliatan does not only interact and share information with its members but also does the same with other desa adat. This is vital in order to hone information and knowledge concerning the experiences undertaken by other desa adat so that they can be utilized as lessons learned for Desa Adat Peliatan and vice versa. Communication and open access to information must be constantly developed in order to reduce potential misunderstandings that may have dire consequences in the implementation of Desa Adat Peliatan's existing system. Open access to information is currently supported with technological sophistication, allowing most things to be carried out instantly with ease. Thus, it can be stated that the dissemination of information to all elements that are involved and uninvolved in Sabha Desa must continue to be conducted, and should be regarded as a crucial point in the collaboration process.

\subsection{Access to Resources}

The implementation of desa adat's programs undoubtedly requires several varieties of resources in terms of personnel, finance, and technical means, in order to achieve the common goal that they have previously agreed upon. In relation to the program implementation at Desa Adat Peliatan, the indigenous collaborative governance in the process of decisionmaking also requires the availability of these various resources, in order to 
support the performance of desa adat itself. According to Article 10 of Regulation of the Minister of Home Affairs No. 113 of 2014 concerning Village Financial Management, financial assistance for desa adat is derived from several sources, such as for instance Village Budget (Anggaran Pendapatan dan Belanja Daerah - APBD from the central government, and Special Financial Assistance (Bantuan Keuangan Khusus - BKK) provided by the regional governments, namely the provincial or regional administrations.

In addition to that, technical resources can also be obtained, as mentioned in an interview with Kelihan Banjar Adat Yangloni of Desa Adat Peliatan, in which it was stated that there are several considerations in decision-making at Desa Adat Peliatan, namely: 1) awig-awig and perarem (technical guideline on the implementation of awig-awig), 2) sima and dresta, situation or conditions that have been inherited and the community themselves have no knowledge of their referred origin, yet they have been around since a long time ago, and are very rarely violated 3) consensus outside of awig-awig and perarem, 4) strategic policy made or sense displayed by the relevant stakeholder that is indeed considered necessary to carry out although they are not specifically discussed in the regulations.

Related to access to resources, it can be seen from collaboration in terms of decision making to discuss Village Budget which is done through village deliberations, and all elements are included. A clear structure of membership in the indigenous collaborative governance of Sabha Desa stands as proof that there is a well-defined pool of human resources that are able to support the collaboration process, particularly in the context of the decision-making process in desa adat. The entire explanation above proves that resources are a vital element in implementing collaboration at the desa adat level and are influential to the performance shown by the desa adat itself.

\section{Conclusion}

The involvement of indigenous collaborative governance in the process of decision-making at Desa Adat Peliatan is established based on several basic indicators found in the collaborative governance. Those indicators might be implemented in the process of decision-making in desa adat in order to acquire a decisive result that is representative of the entire elements present in the community for the sake of conducting the adat community's interests in itself. That decision should also be in accordance with the traditions that they commonly apply, and should not stand in opposition to the prevailing customs. The first indicator to consider is network structure, which discusses the availability of clear and structured arrangements of actors in the decision-making process in Peliatan's Sabha Desa. The following indicator is the commitment to a common purpose or mission, 
which requires the institution to have a common objective and clear mission in implementing the decision-making process in desa adat. Trust and governance explain the implementation of programs at Desa Adat Peliatan which requires deliberation and consensus, agreement, and clear procedures such as awig-awig and perarem. This is meant to create a more structured and well-defined collaboration process in decision-making. Network management talks about the synergy occurring throughout all the elements of indigenous collaborative governance for the common purpose of resolving problems and accomplishing desired goals.

Subsequently, access to authority and leadership enables actors and leaders to wield the authority of making decisions, when confronted with a problem, and they are entrusted by the community to provide a positive influence on the impact brought about by their decision. In the decisionmaking process that occurs in Sabha Desa, distributive accountability and responsibility also have quite a significant influence in determining the capacity an organizational level has in problem-solving. Each of the elements has its respective portion in resolving customary issues/cases, and it is impossible for an individual party to resolve them. All of the parties involved in the decision-making process of the desa adat must certainly possess clear information, to avoid misunderstandings in the collaboration process. This is also the case with the availability of funding and human resources, which also play significant roles in the collaboration process, and the implementation of Sabha Desa in desa adat. Since it is through the availability of those resources alone that the concept of indigenous collaborative governance in the decision-making process can truly be realized.

\section{Book}

\section{BIBLIOGRAPHY}

Atkinson, J. Qualitative Methods. In Journey into Social Activism: Qualitative Approaches pp. 65-98. New York: Fordham University, 2017.

Beresford, B. \& Sloper, T. Understanding the Dynamics of Decision-Making and Choice: a Scoping Study of Key Psychological Theories to Inform the Design and Analysis of the Panel Study. Social Policy Research Unit, University of York, 2008.

Coulter, Angela \& Collins, Alf. Making Shared Decision-Making a Reality. The King's Fund: London, 2011.

Damayana, I.W. Menyama Braya: Studi Perubahan Masyarakat Bali. Salatiga: Universitas Kristen Satya Wacana, 2011.

Davidson, J.S., Henley, D., \& Moniaga, S. Adat Dalam Politik Indonesia. Jakarta: Yayasan Pustaka Obor Indonesia, 2010.

Goldsmith, S., and Donald F. K. Unlocking the power of networks: keys to high- performance government. Brookings Institution Press: Washington, D.C, 2009. 
Jackson, B. How do we know what information sharing is really worth? Exploring methodologies to measure the value of information sharing and fusion efforts. In How Do We Know What Information Sharing Is Really Worth? Exploring Methodologies to Measure the Value of Information Sharing and Fusion Efforts (pp. 1-32). RAND Corporation, 2014.

Ratner, Blake D., Benoy Barman, Philippa Cohen, K. Mam, K. Nagoli, and Edward H. Allison. "Strengthening governance across scales in aquatic agricultural systems", 2012.

Soekanto, S. Hukum Adat Indonesia. Jakarta: PT. Rajagrafindo Persada, 2011.

Tharenou, Phyllis. \& Donohue, Ross. \& Cooper, Brian. Management Research Methods. Cambridge: Port Melbourne, Victoria: Cambridge University Press, 2007.

Vuorinen, J. Decision Making Models and Tools to Support Strategic Decision Making - Case: Tarvekaluste Oy. Saimaa University of Applied Sciences, 2014.

Wiana, I.K. Tri Hita Karana Menurut Konsep Hindu. Surabaya: Paramita Publisher, 2007.

Windia, W.P. Hukum Adat Bali: Aneka Kasus dan Penyelesaiannya. Department of Culture in Gianyar Regency \& Udayana University Press, 2015.

Yin, Robert K. Case Study Research: Design and Methods. Thousand Oaks, CA: Sage, 2009.

Zadek, S. \& Radovich, S. Governing Collaborative Governance: Enhancing Development Outcomes by Improving Partnership Governance and Accountability. John F. Kennedy School of Government: Harvard University, 2006.

\section{Journal Article}

Al-Tarawneh, Hussien Ahmad. "The main factors beyond decision making." Journal of Management Research 4, no. 1 (2012): 1-23.

Ansell, Chris, and Alison Gash. "Collaborative governance in theory and practice." Journal of public administration research and theory 18 , no. 4 (2008): 543-571.

Ari Dalem, A.A. Gd. Bgs.Trisna; Dewi, A.A. Istri Ari Atu; Laksana, I Gusti Ngurah Dharma. Eksistensi Pengelolaan Bersama Tanah Kuburan (Setra) Di Desa Pakraman Peliatan Ubud-Gianyar. Kertha Desa, 1 no 1 (2018), 1-16.

Benton, J. Edwin. "Local government collaboration: Considerations, issues, and prospects." State and Local Government Review 45, no. 4 (2013): 220-223. https://doi.org/10.1177/0160323X13515683

Bertelli, Anthony M., and Craig R. Smith. "Relational contracting and network management." Journal of Public Administration Research and Theory 20, no. suppl_1 (2010): $121-140$. https: / / doi.org/10.1177/0160323X13515683

Emerson, Kirk, Tina Nabatchi, and Stephen Balogh. "An integrative framework for collaborative governance." Journal of public 
administration research and theory 22, no. 1 (2012): 1-29. https://doi.org/10.1093/jopart/mur011

Gunningham, Neil. "The new collaborative environmental governance: The localization of regulation." Journal of Law and Society 36, no. 1 (2009): $\quad 145-166$.

https://doi.org/10.1111/j.1467-

6478.2009.00461.x

Hendriatiningsih, S., A. Budiartha, and Andri Hernandi. "Masyarakat dan Tanah Adat di Bali (Studi Kasus Kabupaten Buleleng, Provinsi Bali)." Jurnal Sosioteknologi 7, no. 15 (2008): 517-528.

Hodgson, Geoffrey M. "What are institutions?." Journal of economic issues 40, no. 11 (2006): https: / / doi.org/10.1080/00213624.2006.11506879

Johnston, Erik W., Darrin Hicks, Ning Nan, and Jennifer C. Auer. "Managing the inclusion process in collaborative governance." Journal of Public Administration Research and Theory 21, no. 4 (2011): 699-721. https: / / doi.org/10.1093/jopart/muq045

Johnston, Melissa P. "Secondary data analysis: A method of which the time has come." Qualitative and quantitative methods in libraries 3, no. 3 (2017): 619-626.

Jonassen, David H. "Designing for decision making." Educational technology research and development 60, no. 2 (2012): 341-359. https://doi.org/10.1007/s11423-011-9230-5

Koski, Chris, Saba Siddiki, Abdul-Akeem Sadiq, and Julia Carboni. "Representation in collaborative governance: A case study of a food policy council." The American Review of Public Administration 48, no. 4 (2018): 359-373. https://doi.org/10.1177/0275074016678683

$\mathrm{Li}$, Bin. "The classical model of decision making has been accepted as not providing an accurate account of how people typically make decisions." International Journal of Business and management 3, no. 6 (2008): 151-154.

Lunenburg, Fred C. "The Decision Making Process." In National Forum of Educational Administration \& Supervision Journal, vol. 27, no. 4. 2010.

Mahardika, I.K.G.M., A.A.G.D Sudarsana, \& A.A.G Sugianthara. Telajakan identification in Desa Pakraman Nyuh Kuning, Kecamatan Ubud Kabupaten Gianyar. E-Journal of Landscape Architecture, 2 no. 1 (2016), 22-31

Manuaba, I.B.P. Wacana Dominan dalam teks awig-awig. Journal of Airlangga University, Surabaya, 23 no. 3 (2010).

Metcalf, Louise, and Sue Benn. "Leadership for sustainability: An evolution of leadership ability." Journal of business ethics 112, no. 3 (2013): 369-384. https:/ / doi.org/10.1007/s10551-012-1278-6

Morse, Ricardo S., and John B. Stephens. "Teaching collaborative governance: Phases, competencies, and case-based learning." Journal of Public Affairs Education 18, no. 3 (2012): 565-583. https://doi.org/10.1080/15236803.2012.12001700 
Negulescu, Oriana-Helena. "Using a decision-making process model in strategic management." Review of General Management 19, no. 1 (2014): 111-123.

Ohorella, Syarif, Didik Suharjito, and Iin Ichwandi. "Efektivitas kelembagaan lokal dalam pengelolaan sumber daya hutan pada masyarakat Rumahkay di Seram Bagian Barat, Maluku." Jurnal Manajemen Hutan Tropika 17, no. 2 (2011): 49-55.

Perlman, Bruce. "Introduction: Risks and Rewards in State and Local Collaboration." State and Local Government Review 43, no. 1 (2011): 46-48. https://doi.org/10.1177/0160323X11400210

Pirson, Michael, and Deepak Malhotra. "Foundations of organizational trust: What matters to different stakeholders?." Organization Science 22, no. 4 (2011): 1087-1104. https://doi.org/10.1287/orsc. 1100.0581.

Purdy, Jill M. "A framework for assessing power in collaborative governance processes." Public administration review 72, no. 3 (2012): 409-417. https://doi.org/10.1111/j.1540-6210.2011.02525.x

Robinson, Jennifer. "Marta Sinclair, Jutta Tobias, and Ellen Choi. "More dynamic than you think: Hidden aspects of decisionmaking." Administrative Sciences 7, no. 3 (2017): 23. https: / / doi.org/10.3390/admsci7030023

Rumiartha, I.N.P.B. "Status of village-owned land transfer into the district government assets in Kintamani Bangli Bali." IUS Journal II 6 (2014); 604.

Rumiartha, I. Nyoman Prabu Buana. "Status of Village-owned Land Transfer Into the District Government Assets in Kintamani Bangli Bali." Jurnal IUS Kajian Hukum dan Keadilan 2, no. 3 (2014).601614. http://dx.doi.org/10.12345/ius.v2i6.190

Sabri, Ahmad. "Kebijakan dan Pengambilan Keputusan Dalam Lembaga Pendidikan Islam." Al-Ta lim Journal 20, no. 2 (2013): 373-379. http://dx.doi.org/10.15548/jt.v20i2.34

Sanjaya, Dewa Bagus. "Harmonisasi, Integrasi Desa Pakraman dengan Desa Dinas yang Multi Etnik dan Multiagama Menghadapi Pergeseran, Pelestarian, dan Konflik di Bali." Jurnal Ilmu Sosial dan Humaniora 2, no. 2 (2013). 265-274. http:/ / dx.doi.org/10.23887/jish-undiksha.v2i2.2183

Scopelliti, Alessandro. "The Political Decision-Making Process in the Council of the European Union under the New Definition of a Qualified Majority." Il Politico (2008): 180-210.

Sugiantari, AA Putu Wiwik, and Lis Julianti. "Peranan Awig-awig Desa Pakraman Dalam Mencegah Tindak Pidana Pencurian Benda Sakral Di Desa Pelaga Kecamatan Petang Kabupaten Badung." Jurnal Bakti Saraswati (JBS) 5, no. 1 (2016).

Susylawati, Eka. "Eksistensi hukum adat dalam sistem hukum di Indonesia." Al-Ihkam: Jurnal Hukum dan Pranata Sosial 4, no. 1 (2013): 124-140.

Tuomela, Raimo. "Collective acceptance, social institutions, and social reality." American Journal of Economics and Sociology 62, no. 1 (2003): 123-165. https://doi.org/10.1111/1536-7150.t01-1-00005 
Van Ast, Jacko A., Anindya Widaryati, and Mansee Bal. "The 'Adat' institution and the Management of Grand Forest 'Herman Yohannes' in Indonesian Timor: The Role of Design Principles for Sustainable Management of Common Pool Resources." Conservation and Society 12, no. 3 (2014): 294-305.

Warm, David. "Local government collaboration for a new decade: Risk, trust, and effectiveness." State and Local Government Review 43, no. 1 (2011): 60-65. https://doi.org/10.1177/0160323X11400436

Weir, Margaret, Leslie Lenkowsky, Romand Coles, and Patrick J. Deneen. "Collaborative Governance and Civic Empowerment A Discussion of Investing in Democracy: Engaging Citizens in Collaborative Governance." (2010): 595-607.

Widyastini, Tyas, and Arya Hadi Dharmawan. "The Effectiveness of Awigawig in Livelihood Arrangements of Fishing Community in Kedonganan Beach." Sodality: Jurnal Sosiologi Pedesaan 1, no. 1 (2015).

\section{Law and Regulation of the Republic of Indonesia}

Law No. 6 of 2014 concerning Villages

Law No. 23 of 2014 concerning Regional Government

Regulation of the Minister of Home Affairs No. 113 of 2014 concerning Village Financial Management

Regional Regulation of Bali Province No. 4 of 2019 concerning Customary Villages in Bali 